\title{
Original \\ Effect of Colchicine Administration on the Structure of the Spleen of Adult Male Albino Rat: Histological and Immunohistochemical Study
} Article

\author{
Enas Anwar Bekheet
}

Anatomy Department, Faculty of Medicine, Ain Shams University, Egypt

\begin{abstract}
Background: Colchicine is a natural alkaloid derived from autumn crocus; it is used in the treatment of gout and in preventing familial Mediterranean fever attacks. It accumulates in many organs such as spleen and may lead to their damage.

Aim: This work aimed to study short and long duration effects of colchicine administration on the structure of the spleen of the adult male albino rat.

Material and Methods: Forty-five adult male albino rats were used in this study, aged from 4-6 months, weighting 150 -180 gm. Rats were equally divided into three groups: Group I: It was further equally subdivided into three subgroups: subgroup IA: Kept as a negative control, subgroup IB: received $1 \mathrm{ml}$ of distilled water/day orally for seven days and subgroup IC: received $1 \mathrm{ml}$ of distilled water/day orally for 30 days. Group II: received $3 \mathrm{mg} / \mathrm{Kg}$ body weight/ day of colchicine orally for seven days. Group III: received colchicine as those of group II but for 30 days.

Results: The present work revealed that administration of colchicine for short duration induced mild structural alteration of rat's spleen in the form of reduction in lymphoid follicles size and subcapsular congestion of blood vessels, while, marked structural alteration of rat's spleen was noticed in group III that received colchicine for long duration in the form of loss of distinction between the white and red pulps with nearly unidentifiable lymphoid follicles and marked parenchymal congested blood vessels.

Conclusion: Colchicine administration induced structural alteration of rat's spleen which was mild with short term use and extensive with long term use.
\end{abstract}

Received: 23 September 2019, Accepted: 26 October 2019

Key Words: Colchicine, red pulp, spleen, white pulp.

Corresponding Author: Enas Anwar Bekheet, M.D., Anatomy Department, Faculty of Medicine, Ain Shams University, Egypt, Tel.: +20 1224037554, E-mail: eno.anatomy@yahoo.com

ISSN: 1110-0559, Vol. 43, No.2

\section{INTRODUCTION}

The spleen is an encapsulated organ and it is considered the largest secondary lymphoid organ containing about one-fourth of the body's lymphocytes ${ }^{[1]}$. It performs both immune and hematopoietic functions, its red pulp is responsible for blood filtration and the white pulp is responsible for the immune function ${ }^{[2]}$. The structural organization of the spleen allows it to filter blood from pathogens and abnormal cells and facilitate interactions between antigen presenting cells and cognate lymphocytes. The antigen presenting cells regulate the $T$ and $B$ cell response to these pathogens ${ }^{[3]}$.

Colchicine is a natural alkaloid with weak antiinflammatory activity derived from the autumn crocus "Colchicum automnale". It is used in the treatment of gout and it is recommended in preventing familial Mediterranean fever attacks especially, in children. It is used also in the treatment of primary biliary cirrhosis, amyloidosis, condyloma acuminate and it is widely used in other several diseases ${ }^{[4]}$.
Colchicine has a potent anti-mitotic activity by binding selectively to tubulin, the microtubular protein that disrupts the function of the mitotic spindles of dividing and migrating cells ${ }^{[5]}$.

Colchicine is rapidly absorbed after oral administration and primarily metabolized by the liver. It undergoes significant enterohepatic re-circulation, and it is also excreted by the kidneys ${ }^{[6]}$. It has a narrow therapeutic index and it accumulates in many organs such as kidney, liver and spleen which may lead to their damage ${ }^{[7-8]}$. Therefore, the present work designed to study short and long duration effects of colchicine administration on the spleen of adult male albino rat.

\section{MATERIALS AND METHODS}

\section{Chemicals}

Colchicine was purchased from Sigma medical company of pharmaceutical industries in the form of powder $100 \mathrm{mg} /$ Pack. 


\section{Animals}

Forty-five adult male albino rats were used in this study, aged from 4-6 months, weighting 150 -180 gm, they were obtained and locally bred at the animal house of the Medical Research Center of Faculty of Medicine, Ain-Shams University. Rats were housed in medium sized metal cages in a room temperature with regular dark/light cycles with good ventilation. Free diet and water access were allowed, and all rats were kept under the same circumstances throughout the experiment. the experiment followed the guidelines of Ain Shams University Ethics Committee.

\section{Experimental Protocol}

Rats were equally divided into three groups (fifteen rats in each group): Group I (Control Group): It was further equally subdivided into three subgroups ( 5 rats in each subgroup): subgroup IA (Negative Control): each rat received nothing but food and water, subgroup IB: each rat received $1 \mathrm{ml}$ of distilled water/day orally by a gastric tube for seven days and subgroup IC: received $1 \mathrm{ml}$ of distilled water /day orally by a gastric tube for 30 days. Group II [Colchicine for short duration]: each rat received $3 \mathrm{mg} / \mathrm{Kg}$ body weight/day of colchicine, the calculated dose was dissolved in $1 \mathrm{ml}$ of distilled water and given orally by a gastric tube for seven days ${ }^{[9]}$. Group III [Colchicine for long duration]: each rat received $3 \mathrm{mg} / \mathrm{Kg}$ body weight/day of colchicine as those of group II but for 30 days.

\section{Processing of Samples}

\section{Preparation of Paraffin Blocks and Staining Methods}

Splenic specimens were fixed in $10 \%$ buffered formalin, processed and embedded in paraffin blocks, sectioned at $5 \mu \mathrm{m}$ and stained by Hematoxylin and $\operatorname{Eosin}^{[10]}$ (Hx. and E.) and other sections were stained with Masson's trichrome stain to clarify the collagen fibers ${ }^{[11]}$.

Immunohistochemical study for the proliferating cell nuclear antigen (PCNA) as a marker for DNA integrity, $5 \mu \mathrm{m}$ sections were used and incubated in mouse monoclonal anti-PCNA antibody (Dako PC10) at a dilution of 1 in 100 in Tris-buffered saline (TBS) (pH 7.6). Then were washed in phosphate-buffered saline. Visualization of reaction was done using the standard anti-alkaline-phosphatase labelling method, then counterstained by hematoxylin ${ }^{[12]}$.

Immunohistochemical study for $\mathrm{CD} 4$ as a marker for CD4 positive immune cells, sections were incubated with $1200 / \mathrm{CD} 4$ for $1.5 \mathrm{~h}$ at room temperature and rinsed with phosphate-buffered saline, then incubated for $1 \mathrm{~h}$ with anti-mouse immunoglobulins conjugated to peroxidaselabeled dextran polymer (Dako, Denmark). Then the slides were incubated in 3,3 Diaminobenzidine for 15 mins, then counterstained by hematoxylin ${ }^{[13]}$.

Stained sections were examined and photographed using light microscope (Olympus 268M microscope) equipped with an automatic photomicrographic camera system.

\section{Image Analysis}

Morphometric analysis was carried out using image analyzer Leica Q win V.3 program installed on a computer in the Histology Department, Faculty of Medicine, Ain Shams University. The computer was connected to a Leica DM2500 microscope (Wetzlar, Germany). Six randomly chosen fields in six sections obtained from six different animals from the same group were used, Hx. and E. stained sections were used for measuring the diameter of white pulp lymphoid follicles, Immunohistochemically stained sections for CD4 were used for measuring the number of cells with CD4 immune positive cell membrane in the red pulp, Immunohistochemically stained sections for PCNA were used for measuring the number of nuclear PCNA immune positive cells of splenic parenchyma and Masson's trichrome stained sections were used for measuring the area $\%$ of collagen fibers. The magnification used was $400 \mathrm{X}$ with an objective lens of $40 \mathrm{X}$ for all measures except for the diameter of lymphoid follicles, the magnification used was100X with an objective lens of 10X.

\section{Statistical Analysis}

Data analysis was performed using PSPP freeware with one-way ANOVA and Bonferroni Post Hoc test to detect the significance between every two groups. Results were considered significant when $P$ value $\leq 0.05$ and insignificant when $P$ value $>0.05$.

\section{RESULTS}

\section{Histological Results}

\section{Groups I (Control)}

Light microscopic examination of $\mathrm{Hx}$. and E. stained sections of the control subgroups IA, IB and IC showed almost the same regular structure of the splenic parenchyma which was consisted of white pulp (lymphoid tissue), red pulp (vascular matrix) and marginal zones in-between. The white pulp was formed of lymphoid follicles attached to a sheath of lymphocytes (the peri-arteriolar lymphatic sheath (PALS)) around the central arterioles. The lymphoid follicles composed of lymphocytes aggregates (mantle zone) and some follicles showed germinal center. The follicle was surrounded by the marginal zone (light stained lymphocytes) which was demarcating the lymphoid follicle from the red pulp. The red pulp was composed of anastomosing splenic cords and blood sinusoids inbetween. The spleen was surrounded by a capsule with extending trabeculae into the splenic parenchyma which were traversed by small blood vessels (Figures1-4). Masson's trichrome stain showed the presence of collagen fibers mainly in the capsule and in the extending trabeculae with scattered fibers throughout the parenchyma (Figure 5).

Examination of CD4 immunohistochemically stained sections showed cells with CD4 immune positive cell membrane mainly in the red pulp and mostly arranged in groups with few scattered cells with CD4 immune positive 
cell membrane in the white pulp mostly in the germinal center of the lymphoid follicle (Figures 6,7). While, examination of PCNA immunohistochemically stained sections showed strong positive nuclear immunoreaction for PCNA of most splenic parenchyma cells either of red pulp or white pulp (Figures 8,9).

\section{Group II (Colchicine for Short Duration)}

Light microscopic examination of Hx. and E. stained sections of the group II showed, an apparent reduction in the size of white pulp lymphoid follicles with unidentified marginal zone. Dilated congested subcapsular blood vessels were noticed. The capsule was surrounding the spleen with extending trabeculae into the splenic parenchyma (Figures 10-13). Masson's trichrome stain showed collagen fibers distribution mainly in the capsule and in the extending trabeculae (Figure 14).

Examination of CD4 immunohistochemically stained sections showed apparent reduction in the number of cells with CD4 immune positive cell membrane (Figure 15). Examination of PCNA immunohistochemically stained sections showed apparent reduction in the number of nuclear PCNA immune positive splenic parenchymal cells (Figure 16).

\section{Group III (Colchicine for Long Duration)}

Light microscopic examination of Hx. and E. stained sections of the group III showed, loss of distinction between the white and red pulps with nearly unidentifiable lymphoid follicles of white pulp. Dilated congested blood vessels were noticed, in the subcapsular region and throughout the splenic parenchyma. Wide subcapsular spaces with disturbed architecture of the trabeculae were also noticed (Figures 17-20). Masson's trichrome stain showed apparent thinned out collagen fibers in the capsule and in the extending trabeculae (Figure 21).

Examination of CD4 immunohistochemically stained sections showed apparent marked reduction in the number of cells with CD4 immune positive cell membrane (Figure 22). Examination of PCNA immunohistochemically stained sections showed apparent marked reduction in the number of nuclear PCNA immune positive splenic parenchymal cells (Figure 23).

\section{Morphometrical Results}

I. The statistical analysis of the mean diameter of white pulp lymphoid follicles in $\mu \mathrm{m}$ revealed significant statistical reduction in group II and in group III as compared with those of the control group with a P-value $>0.05$. Additionally, a significant statistical reduction has been found in group III as compared with those of group II with a $P$-value $>0.05$ (Table1 and Column chart1).

II. The statistical analysis of the mean number of cells with CD4 immune positive cell membrane of red pulp/field revealed significant statistical reduction in group II and in group III as compared with those of the control group with a $P$-value $>0.05$. Additionally, a significant statistical reduction has been found in group III as compared with those of group II with a $P$-value $>0.05$ (Table 2 and Column chart 2).

III. The statistical analysis of the mean number of nuclear PCNA immune positive cells of splenic parenchyma/field revealed significant statistical reduction in group II and in group III as compared with those of the control group with a $P$-value $>0.05$. Additionally, a significant statistical reduction has been found in group III as compared with those of group II with a $P$-value $>0.05$ (Table 3 and Column chart 3 ).

IV. The statistical analysis of the mean area \% of collagen fibers/field (including capsule and trabecula) revealed significant statistical reduction in group III as compared with those of the control group and group II with a $P$-value $>$ 0.05. Also, an insignificant statistical reduction has been found in group II as compared with those of the control group with a $P$-value $<0.05$ (Table 4 and Column chart 4).

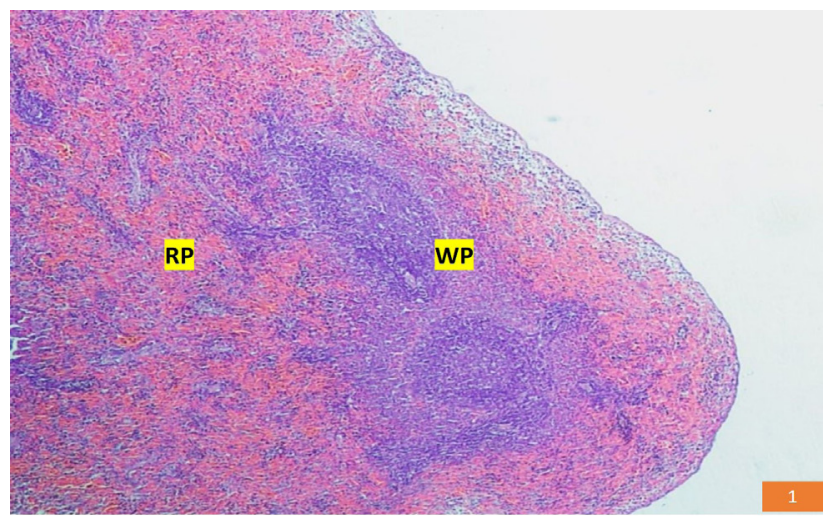

Fig. 1: A photomicrograph of a section of the spleen of the control group showing, the white pulp (WP) and the red pulp (RP). (Hx. \& E. X40)

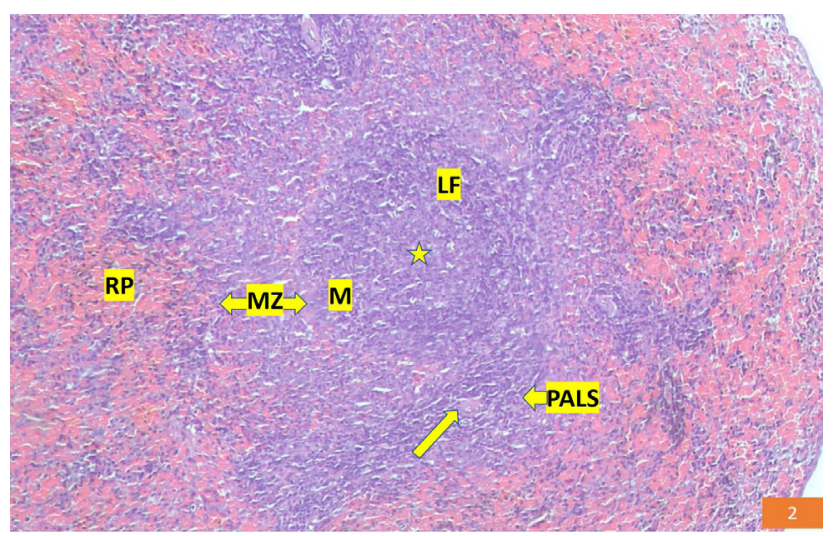

Fig. 2: A photomicrograph of a section of the spleen of the control group showing, white pulp lymphoid follicle (LF) with central germinal center (Star), mantle zone (M), marginal zone (MZ), the central arteriole (long arrow), periarterial lymphatic sheath (PALS) and red pulp (RP). (Hx. \& E. X100) 


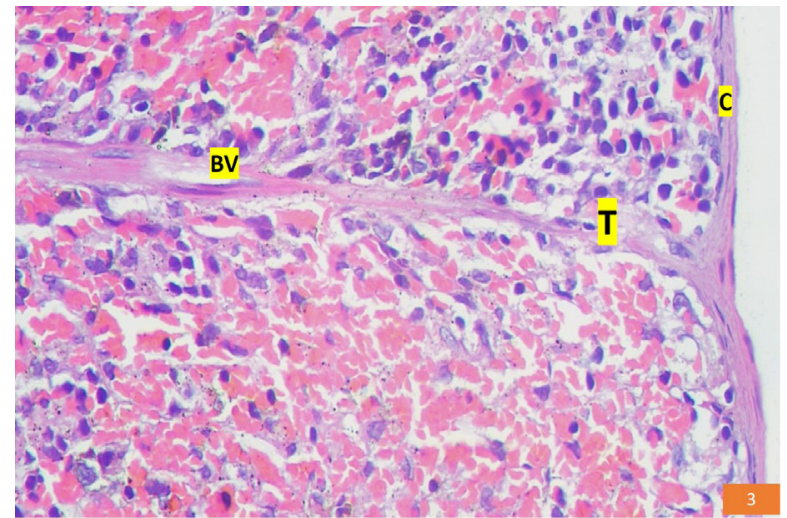

Fig. 3: A photomicrograph of a section of the spleen of the control group showing, the capsule $(\mathrm{C})$ and the extending trabecula $(\mathrm{T})$ with its small blood vessels (BV). (Hx. \& E. X400)

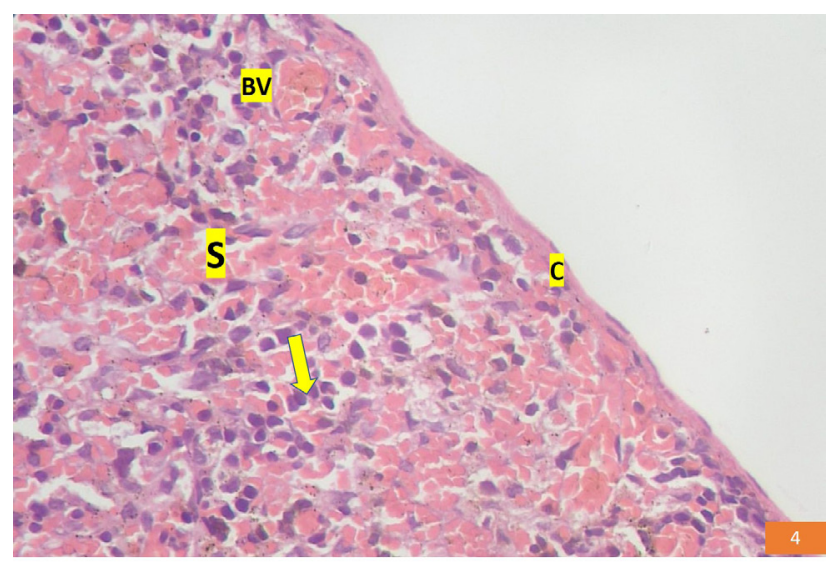

Fig. 4: A photomicrograph of a section of the spleen of the control group showing, the capsule (C), subcapsular blood vessel (BV), red pulp sinusoids (S) and splenic cords of lymphocytes (arrow). (Hx. \& E. X400)

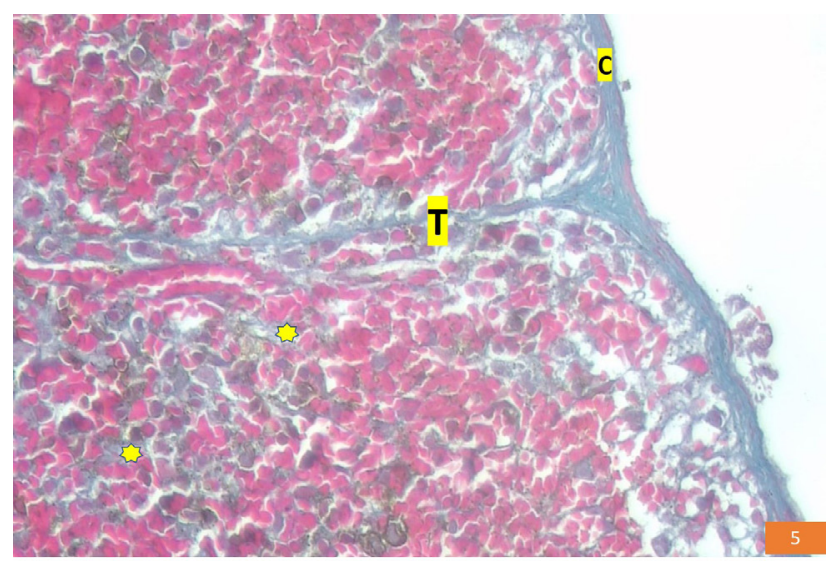

Fig. 5: A photomicrograph of a section of the spleen of the control group showing, collagen fibers mainly in the capsule (C) and in the extending trabeculae $(\mathrm{T})$ with scattered fibers throughout the parenchyma (stars). (Masson's trichrome X400)

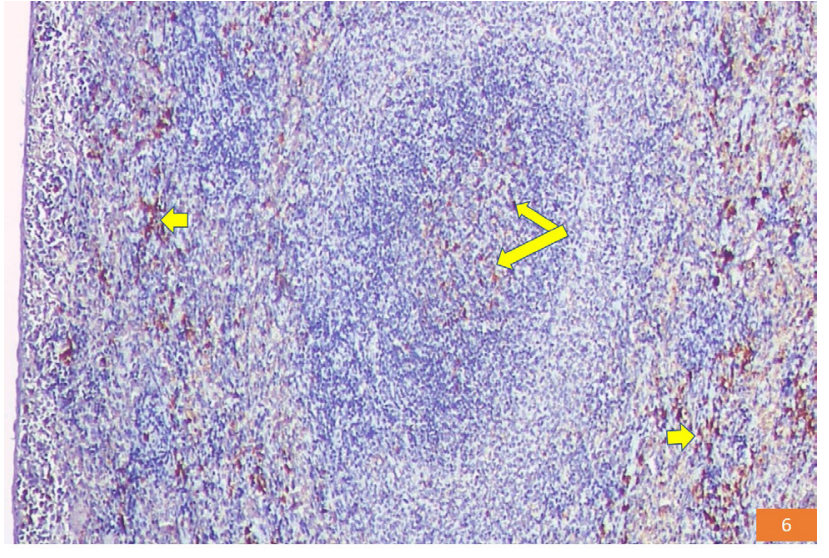

Fig. 6: A photomicrograph of a section of the spleen of the control group showing, CD4 cell membrane immune positive cells mainly in the red pulp (short arrows) and few immune positive cells in the in the germinal center of the lymphoid follicle (long arrows). (CD4, X100)

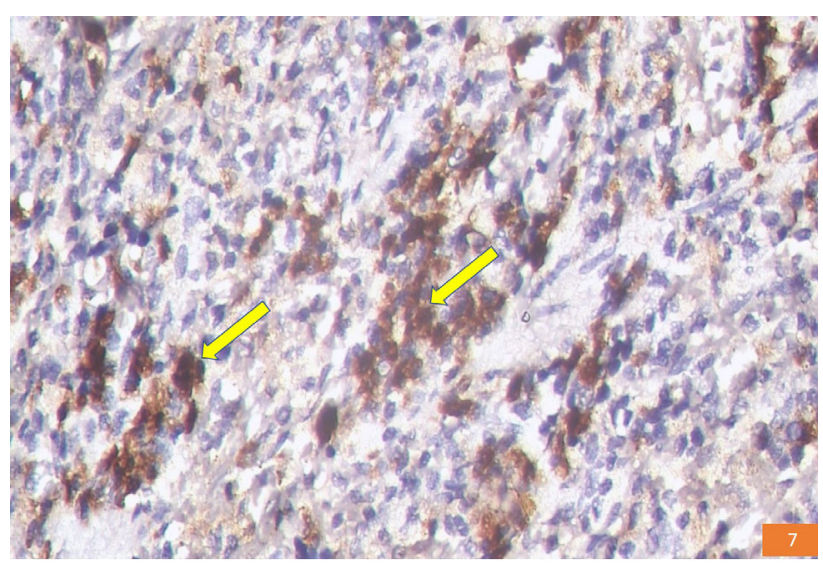

Fig. 7: A photomicrograph of a section of the spleen of the control group showing, CD4 cell membrane immune positive cells (arrows) of the red pulp arranged mostly in groups. (CD4, X400)

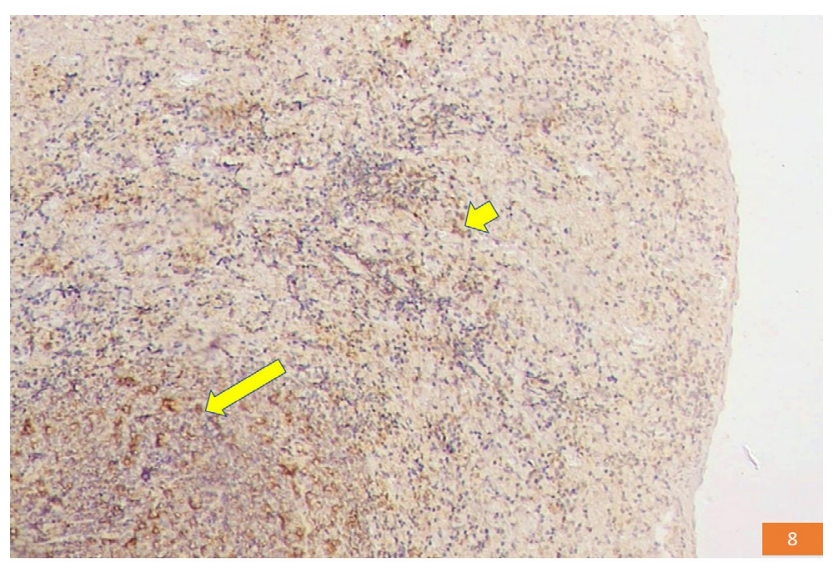

Fig. 8: A photomicrograph of a section of the spleen of the control group showing, strong positive nuclear immunoreaction for PCNA of red pulp cells (short arrow) and white pulp cells (long arrow). (PCNA, X100) 


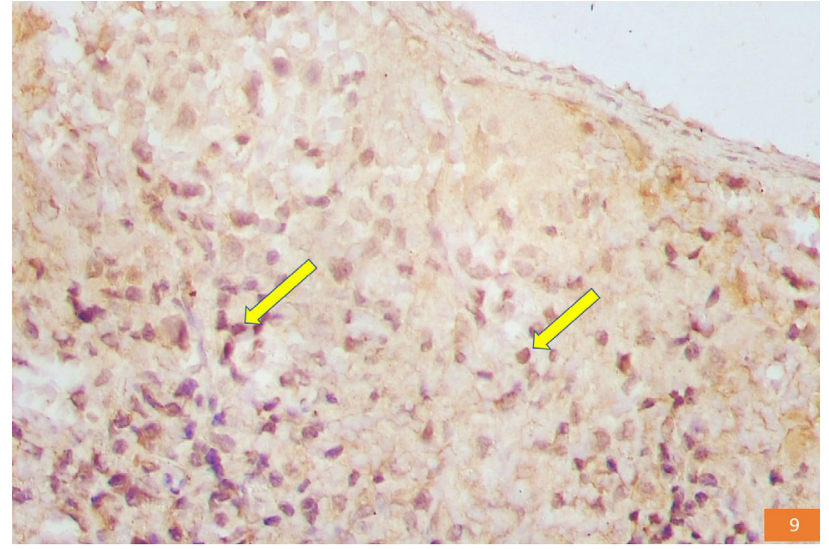

Fig. 9: A photomicrograph of a section of the spleen of the control group showing, strong positive nuclear immunoreaction for PCNA of most splenic parenchyma cells (arrows). (PCNA, X400)

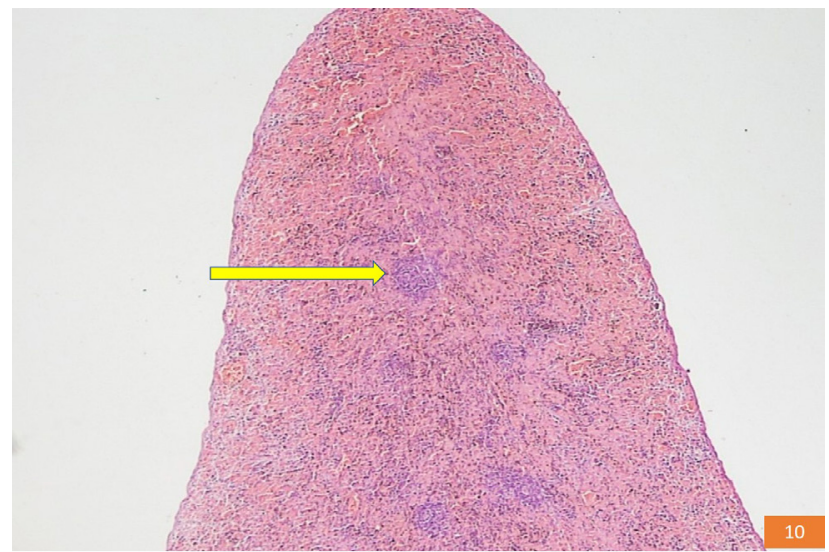

Fig. 10: A photomicrograph of a section of the spleen of group II showing, the white pulp with an apparent reduction in the size of white pulp lymphoid follicles (arrow) as compared to control group. (Hx. \& E. $\mathrm{X} 40$ )

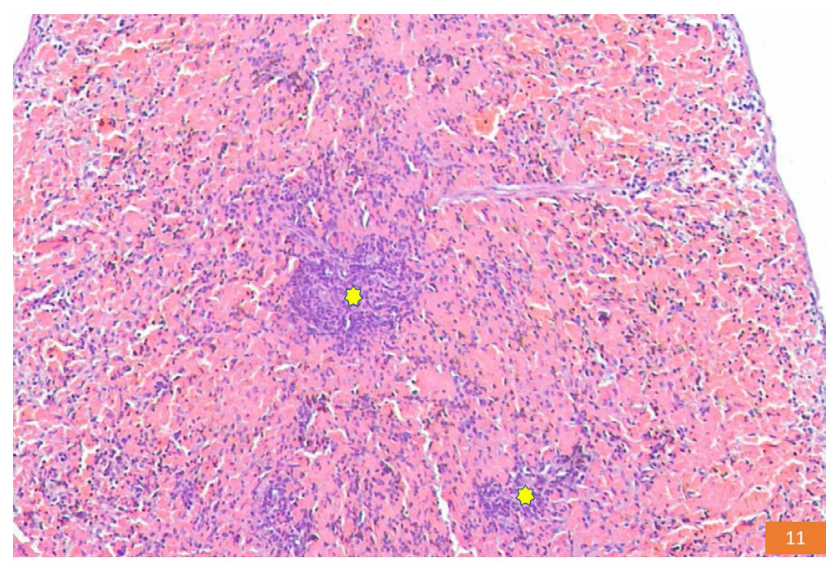

Fig. 11: A photomicrograph of a section of the spleen of group II showing, an apparent reduction in the size of lymphoid follicles (stars) with unidentified marginal zone. (Hx. \& E. X100)

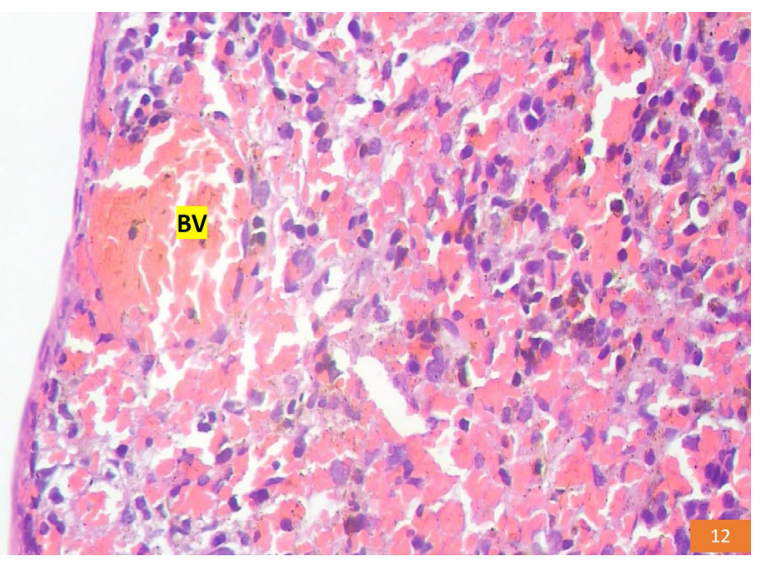

Fig. 12: A photomicrograph of a section of the spleen of group II showing, dilated congested subcapsular blood vessel (BV). (Hx. \& E. X400)

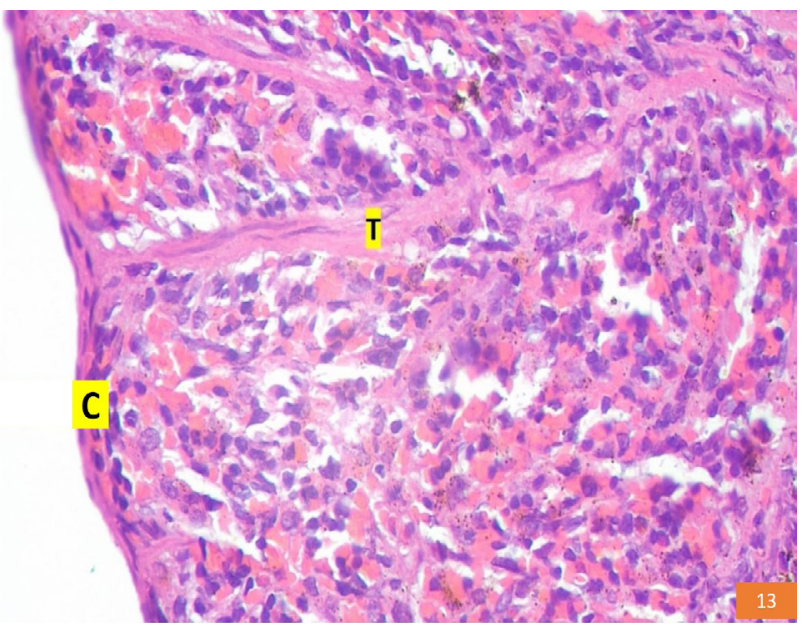

Fig. 13: A photomicrograph of a section of the spleen of group II showing, the surrounding capsule (C) and extending trabecula (T). (Hx. \& E. X400)

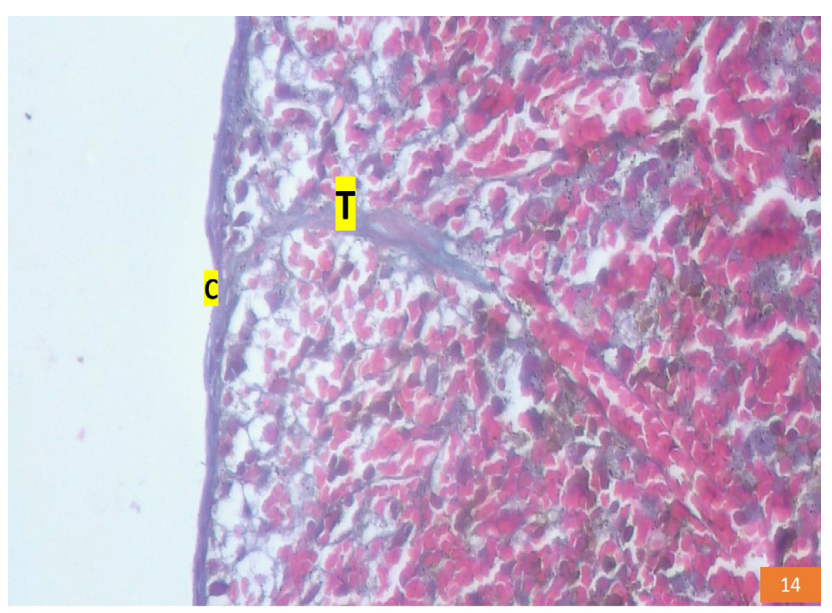

Fig. 14: A photomicrograph of a section of the spleen of group II showing, collagen fibers distribution mainly in the capsule (C) and in the extending trabecula (T). (Masson's trichrome X400) 


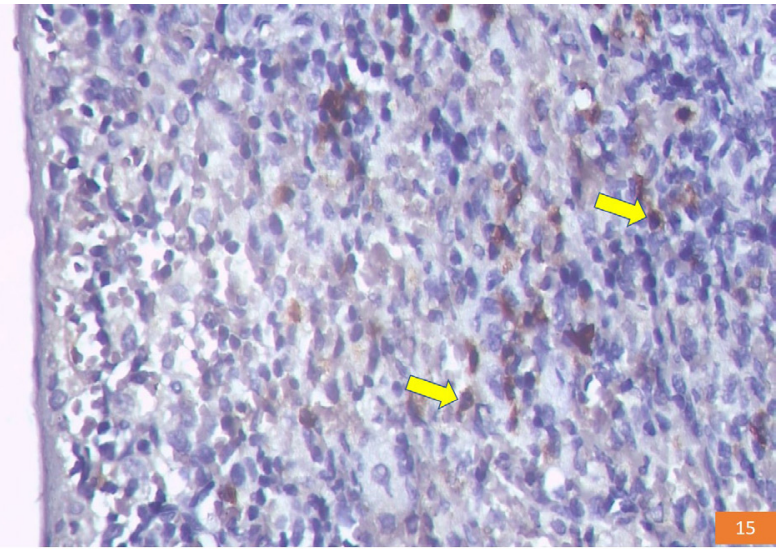

Fig. 15: A photomicrograph of a section of the spleen of group II showing, apparent reduction of CD4 cell membrane immune positive cells of the red pulp (arrows) as compared to control group. (CD4, X400)

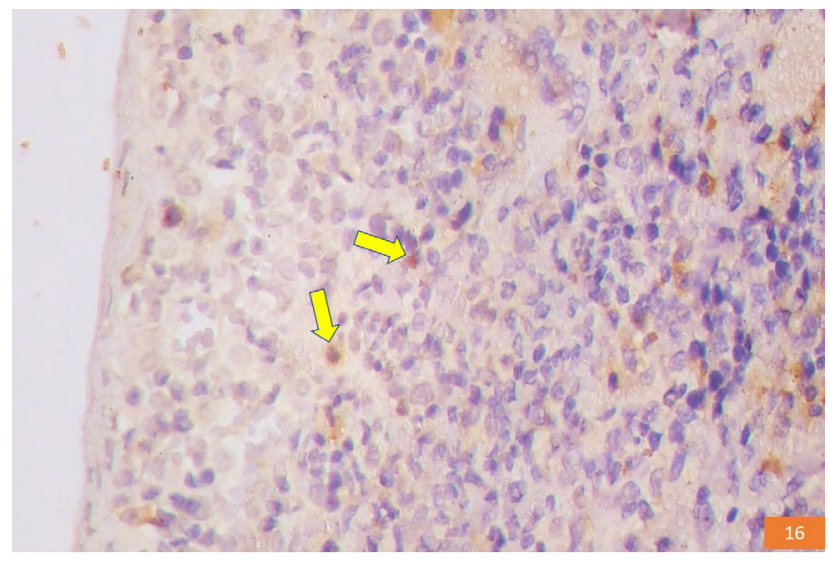

Fig. 16: A photomicrograph of a section of the spleen of group II showing, apparent reduction of nuclear PCNA immune positive cells (arrows) as compared to control group. (PCNA, X400)

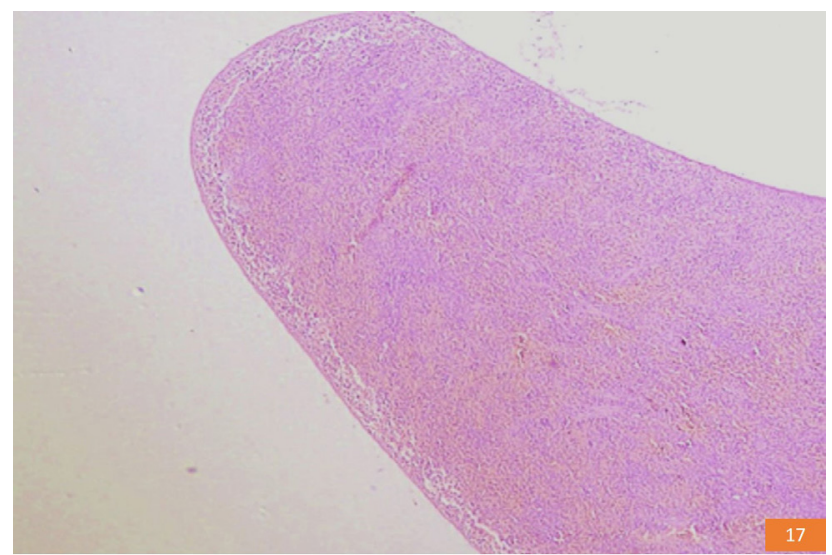

Fig. 17: A photomicrograph of a section of the spleen of group III showing, loss of distinction between the white and red pulps with nearly unidentifiable lymphoid follicles of white pulp as compared to control group and group II. (Hx. \& E. X40)

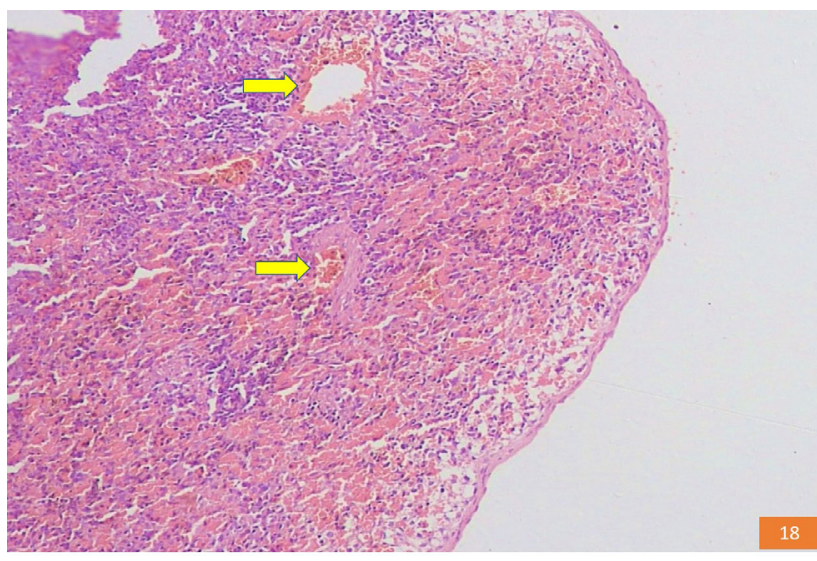

Fig. 18: A photomicrograph of a section of the spleen of the group III showing, unidentifiable lymphoid follicles of white pulp and dilated congested parenchymal blood vessels (arrows). (Hx. \& E. X100)

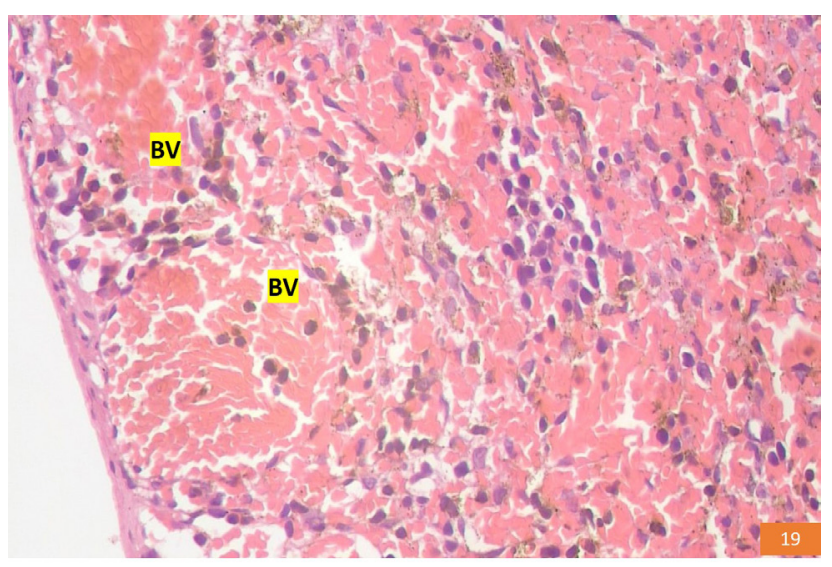

Fig. 19: A photomicrograph of a section of the spleen of the group III showing, subcapsular dilated congested blood vessel (BV). (Hx. \& E. X400)

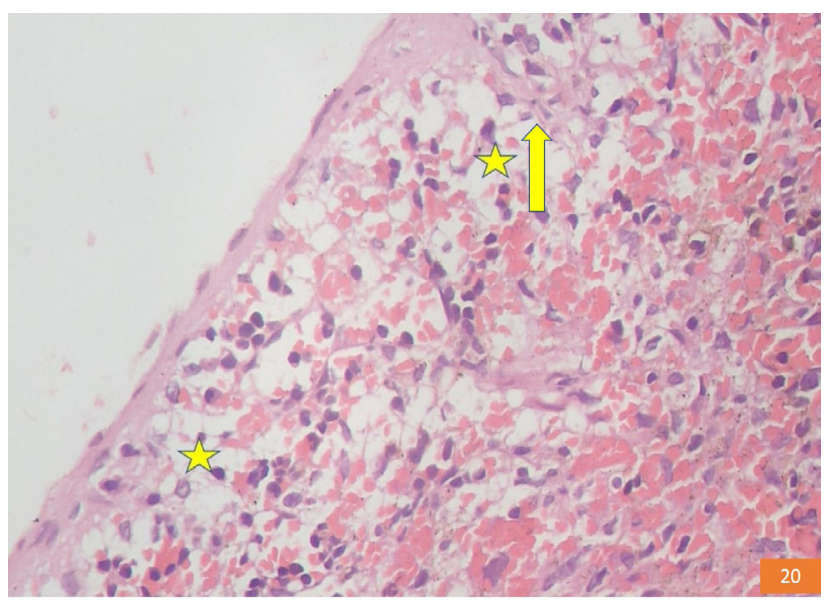

Fig. 20: A photomicrograph of a section of the spleen of the group III showing, wide subcapsular spaces (stars) with disturbed architecture of the trabecula (arrow). (Hx. \& E. X400) 


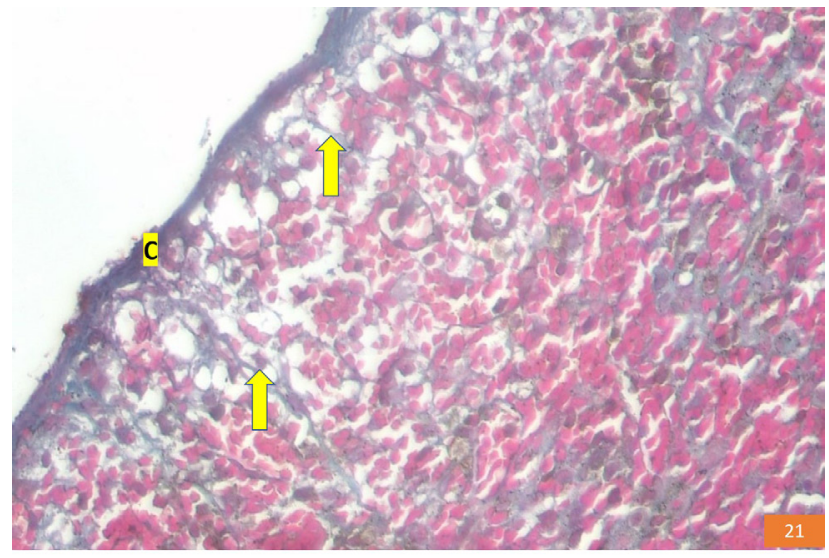

Fig. 21: A photomicrograph of a section of the spleen of group III showing, apparent thinned out collagen fibers in the capsule (C) and in the extending trabeculae (arrows) as compared to control group and group II. (Masson's trichrome X400)

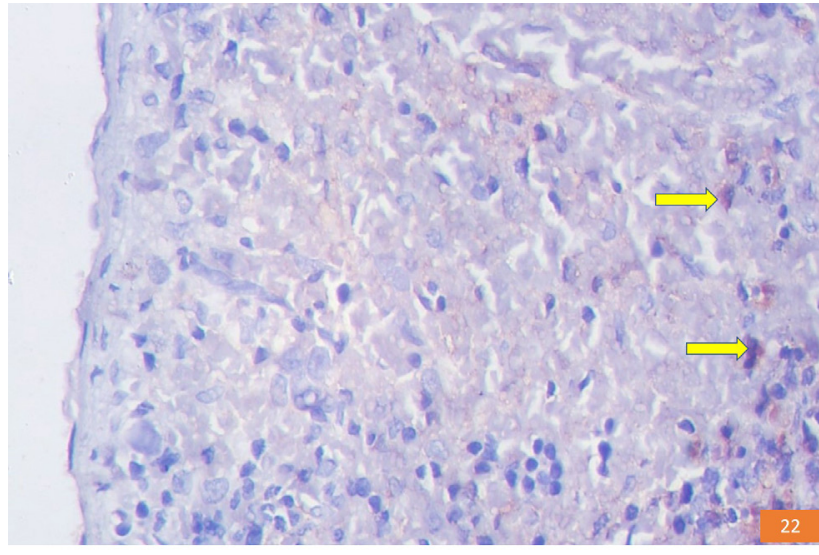

Fig. 22: A photomicrograph of a section of the spleen of group II showing, apparent marked reduction of CD4 cell membrane immune positive cells (arrows) of the red pulp as compared to control group and group II. (CD4, X400)

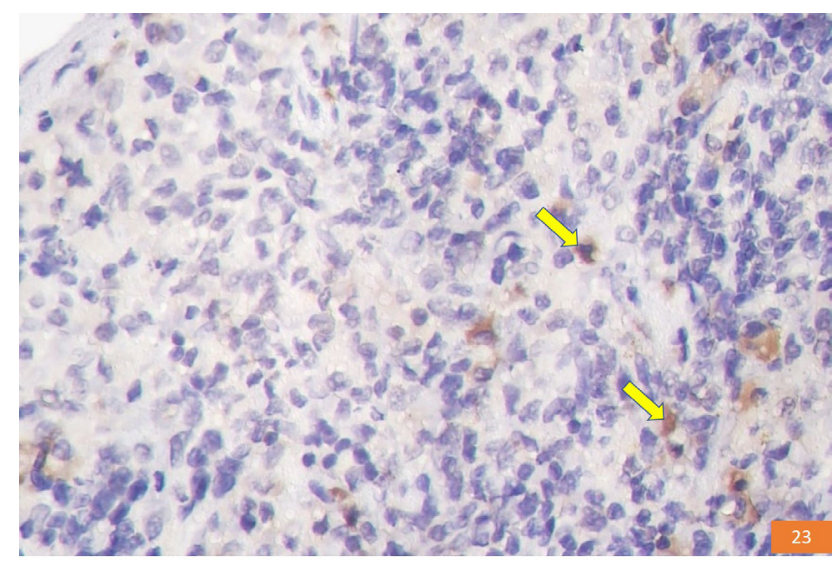

Fig. 23: A photomicrograph of a section of the spleen of group III showing, apparent marked reduction of nuclear PCNA immune positive cells (arrows) as compared to control group and group II. (PCNA, X400)

Table 1: Comparing the mean diameter of white pulp lymphoid follicles in $\mu \mathrm{m}$ showing, $(* *)$ significant $P$-value

\begin{tabular}{|c|c|c|c|c|}
\hline & & $\begin{array}{l}\text { Group I } \\
\text { (Control) }\end{array}$ & $\begin{array}{c}\text { Group II } \\
\text { (Colchicine for short duration) }\end{array}$ & $\begin{array}{c}\text { Group III } \\
\text { (Colchicine for long duration) }\end{array}$ \\
\hline \multicolumn{2}{|c|}{$\begin{array}{l}\text { The diameter of white pulp lymphoid follicles in } \mu \mathrm{m} \\
\text { (mean } \pm \text { standard deviation) }\end{array}$} & $34.4 \pm 3.0$ & $25.4 \pm 1.0$ & $9.8 \pm 1.3$ \\
\hline \multirow{3}{*}{$\mathrm{T}$ test } & Between Group I\&II & & $\mathrm{P}=0.0008^{* *}$ & \\
\hline & Between Group II\&III & & $\mathrm{P}=0.0004^{* *}$ & \\
\hline & Between Group I\&III & & $\mathrm{P}=0.0002^{* *}$ & \\
\hline
\end{tabular}

Table 2: Comparing the mean number of CD4 cell membrane immune positive cells of red pulp/field showing, $(* *)$ significant $P$-value

\begin{tabular}{|c|c|c|c|c|}
\hline & & $\begin{array}{l}\text { Group I } \\
\text { (Control) }\end{array}$ & $\begin{array}{c}\text { Group II } \\
\text { (Colchicine for short duration) }\end{array}$ & $\begin{array}{c}\text { Group III } \\
\text { (Colchicine for long duration) }\end{array}$ \\
\hline \multicolumn{2}{|c|}{$\begin{array}{l}\text { The number of CD4 immune positive cells of red pulp/field } \\
\text { (mean } \pm \text { standard deviation) }\end{array}$} & $56.4 \pm 6.9$ & $34.1 \pm 3.6$ & $9.6 \pm 2.2$ \\
\hline \multirow{3}{*}{$\mathrm{T}$ test } & Between Group I\&II & & $\mathrm{P}=0.0009^{* *}$ & \\
\hline & Between Group II\&III & & $\mathrm{P}=0.0001^{* *}$ & \\
\hline & Between Group I\&III & & $\mathrm{P}=0.0003^{* *}$ & \\
\hline
\end{tabular}


Table 3: Comparing the mean number of nuclear PCNA immune positive cells/field showing, $(* *)$ significant $P$-value

\begin{tabular}{|c|c|c|c|c|}
\hline & & $\begin{array}{l}\text { Group I } \\
\text { (Control) }\end{array}$ & $\begin{array}{c}\text { Group II } \\
\text { (Colchicine for short duration) }\end{array}$ & $\begin{array}{c}\text { Group III } \\
\text { (Colchicine for long duration) }\end{array}$ \\
\hline \multicolumn{2}{|c|}{$\begin{array}{l}\text { The number of PCNA immune positive cells /field } \\
\text { (mean } \pm \text { standard deviation) }\end{array}$} & $47.6 \pm 4.5$ & $24.7 \pm 1.6$ & $7.5 \pm 1.5$ \\
\hline \multirow{3}{*}{ T test } & Between Group I\&II & & $\mathrm{P}=0.0003^{* *}$ & \\
\hline & Between Group II\&III & & $\mathrm{P}=0.0007^{* *}$ & \\
\hline & Between Group I\&III & & $\mathrm{P}=0.0002^{* *}$ & \\
\hline
\end{tabular}

Table 4: Comparing the mean area $\%$ of collagen fibers /field showing, $(* *)$ significant P-value and (*) insignificant P-value

\begin{tabular}{|c|c|c|c|c|}
\hline & & $\begin{array}{l}\text { Group I } \\
\text { (Control) }\end{array}$ & $\begin{array}{c}\text { Group II } \\
\text { (Colchicine for short duration) }\end{array}$ & $\begin{array}{c}\text { Group III } \\
\text { (Colchicine for long duration) }\end{array}$ \\
\hline & $\begin{array}{l}\text { The area } \% \text { of collagen fibers/field } \\
\text { (mean } \pm \text { standard deviation) }\end{array}$ & $45.1 \pm 2.1$ & $44.4 \pm 1.0$ & $25.2 \pm 2.4$ \\
\hline \multirow{3}{*}{$\mathrm{T}$ test } & Between Group I\&II & & $\mathrm{P}=0.2^{* *}$ & \\
\hline & Between Group II\&III & & $\mathrm{P}=0.0001^{* *}$ & \\
\hline & Between Group I\&III & & $\mathrm{P}=0.0003^{* *}$ & \\
\hline
\end{tabular}

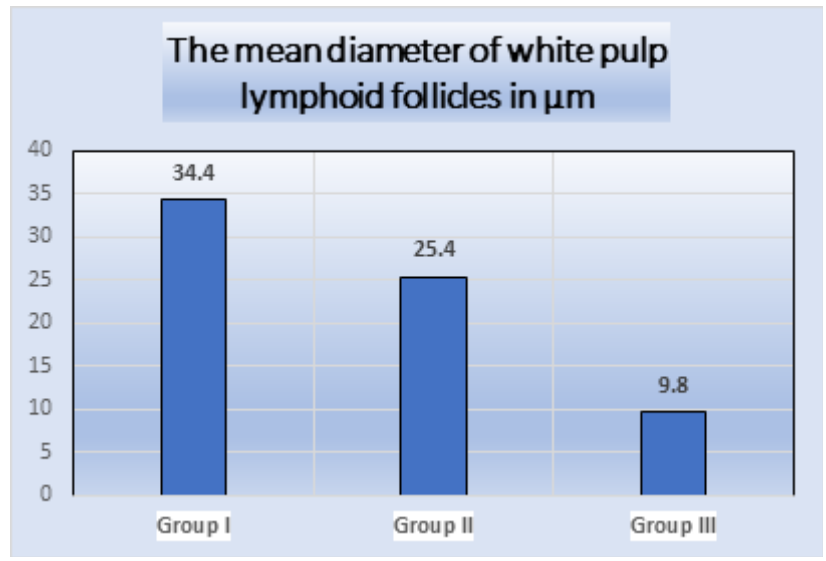

Column chart 1: Demonstrating the morphometric comparison as regards; the mean diameter of white pulp lymphoid follicles in $\mu \mathrm{m}$

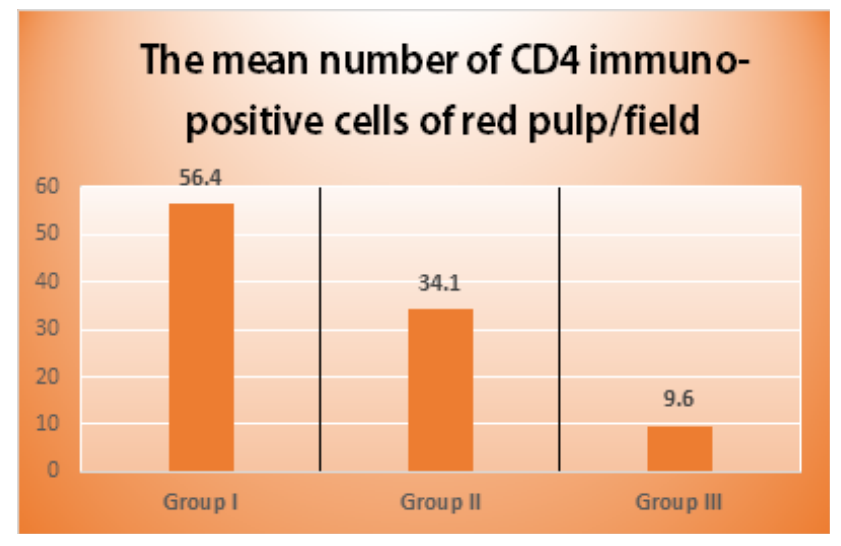

Column chart 2: Demonstrating the morphometric comparison as regards; the mean number of CD4 cell membrane immune positive cells of red pulp/field

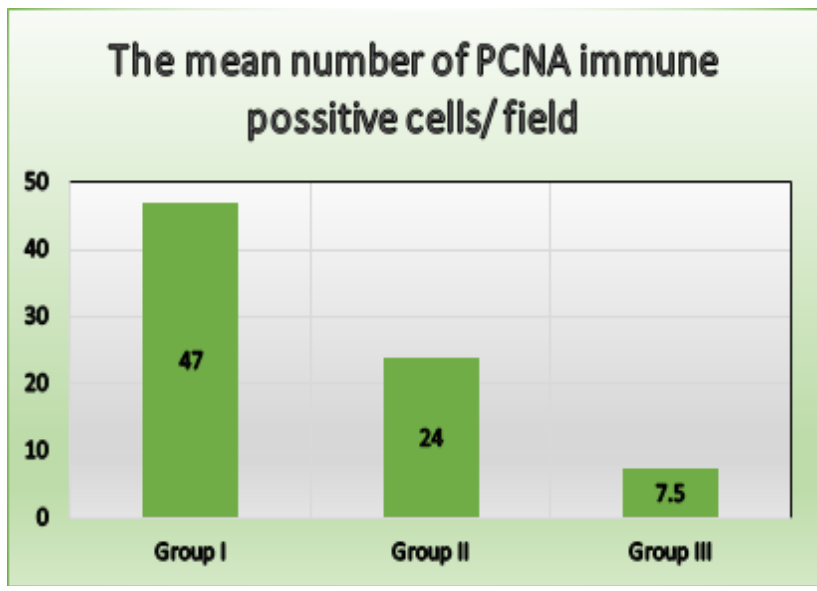

Column chart 3: Demonstrating the morphometric comparison as regards; the mean number of nuclear PCNA immune positive cells/field

\section{The mean area $\%$ of collagen fibers/field}

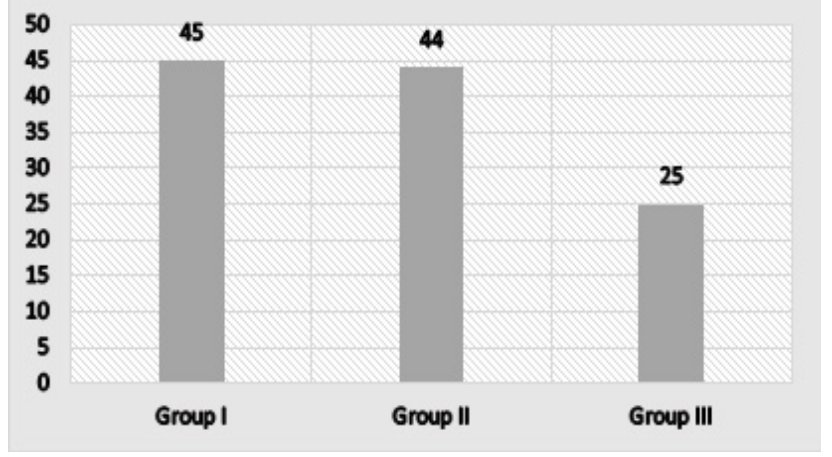

Column chart 4: Demonstrating the morphometric comparison as regards; the mean area \% of collagen fibers/field 


\section{DISCUSSION}

Food and Drug administration (FDA) reported that fatal colchicine toxicity can occur with usual doses in patients with certain risk factors, including impaired renal or hepatic function and in old age patients because of increased susceptibility to cumulative toxicity ${ }^{[14]}$. It has been reported that, the toxic effect of colchicine was depending on the dose and duration of exposure ${ }^{[5]}$. Prolonged use of colchicine is needed in treatment of certain chronic diseases such as gout and familial Mediterranean fever ${ }^{[15]}$.

The results of the present work revealed that administration of colchicine for short duration (Group II) induced mild structural alteration of rat's spleen, while, extensive structural alteration of rat's spleen was noticed in group III that received colchicine for long duration, Hx. and E. stained sections of group II showed reduction of the lymphoid follicles size with unidentified marginal zone which was confirmed by the morphometric results that revealed significant statistical reduction in the mean lymphoid follicles diameters of group II as compared to those of the control group. While, Hx. and E. stained sections of group III showed loss of distinction between the white and red pulps with nearly unidentifiable lymphoid follicles, which was confirmed by the morphometric results that revealed significant statistical reduction in the mean lymphoid follicles diameters compared with those of the control group and similarly with those of group II. Lymphoid follicles are accumulations of migratory B-lymphocytes that arrested within the follicle after antigen recognition for formation of immune complexes. The marginal zone is the region that demarcate the lymphoid follicles from the red pulp and occupied by memory B cells and macrophages ${ }^{[16]}$. A unique feature of lymphocytes is their continuous migration between lymphoid and other organs using the lymphatic and blood vessels as a traffic route. Lymphocyte migration is a prerequisite for continuous representation of antigenic specificities throughout the whole body and in the interaction between accessory cells and lymphoid cells for initiating immune reactions ${ }^{[17]}$. Colchicine is considered an intracellular poison affecting cellular division, intracellular transport system, nuclear structure and cellular migration ${ }^{[18,19]}$. It has been reported that colchicine induced production of echinoderm microtubule associated protein like-1 (EML1), this protein modifies the assembly of microtubules by shortening them thus affecting cytokinesis and cell migration ${ }^{[20]}$. Tsukidate et al . $(1993)^{[21]}$ stated that the disruption of microtubules integrity by colchicine alters the plasma membrane permeability of extracellular calcium ions and induces increased influx of calcium ions resulting in DNA fragmentation and cellular damage.

Group II and Group III both, showed dilated congested subcapsular blood vessels. While, group III also showed dilated congested blood vessels throughout the splenic parenchyma and marked subcapsular spaces with disturbed architecture of the trabeculae. This was in agreement with Nabila (2006) $)^{[4]}$ who reported that colchicine led to histological changes in different organs such as liver, kidney and spleen that showed congestion and subcapsular edema. Wagenaar $(2004)^{[5]}$ stated that accidental colchicine poisoning in a dog caused marked congestion of splenic red pulp.

Moreover, Masson's trichrome stain of group II showed nearly control like distribution of collagen fibers in the capsule and in the extending trabeculae. Whereas, in group III the collagen fibers were apparently thinned out in the capsule and in the extending trabeculae. That was confirmed by the morphometric results that revealed significant statistical reduction of the mean area $\%$ of collagen fibers in group III as compared with those of the control group and group II. while, an insignificant statistical reduction of the mean area \% of collagen fibers has been found in group II as compared with those of the control group. El-Shafeey et al. $(2000)^{[7]}$ reported that colchicine reduced collagen content of the spleen. Additionally, long-term colchicine treatment was proved to exert an anti-inflammatory, anti-fibrotic and immunomodulatory effects and inhibited collagen production and increased collagen degradation in liver cirrhosis ${ }^{[22]}$.

Examination of CD4 immunohistochemically stained sections showed apparent reduction of CD4 immune positive cells in group II and apparent marked reduction in group III which was confirmed by the morphometrical results that revealed significant statistical reduction in the mean number of CD4 immune positive cells of red pulp of group II and III as compared to those of the control group and similarly significant statistical reduction in the mean number of CD4 immune positive cells of red pulp of group III as compared with those of group II. The cluster of differentiation 4 (CD4) is a glycoprotein found on the cell membrane of some immune cells such as T-helper cells (TH) and macrophages. T-helper lymphocytes play a pivotal role in the adaptive immunity, following antigen recognition, naive TH cells are activated and undergo further differentiation then they secrete cytokines to promote and steer the immune response. While, macrophages are large phagocytic and antigen presenting cells which are vital for both innate and adaptive immune response ${ }^{[23-26]}$. El-Shafeey et al. $(2000)^{[7]}$ reported that prolonged colchicine use inhibited the proliferation of B and T-lymphocytes and it also induced apoptosis in T-lymphocytes of the spleen. A reduction in the number of leukocytes [white blood cells] in the blood stream was also detected with colchicine therapy ${ }^{[5]}$ and this effect was explained by the capability of colchicine in inhibiting microtubule assembly that triggered cellular apoptosis ${ }^{[27]}$.

In addition, PCNA immunohistochemically stained sections of group II showed apparent reduction of nuclear PCNA immune positive cells of the splenic parenchymal cells. Whereas, group III showed apparent marked reduction of nuclear PCNA immune positive cells of splenic parenchymal cells. That was confirmed by the morphometric results that revealed significant statistical reduction of the mean number of nuclear PCNA immune 
positive cells of splenic parenchyma in group II and in group III as compared with those of the control group. Also, a significant statistical reduction has been found in group III as compared with those of group II. The proliferating cell nuclear antigen (PCNA) is an auxiliary protein for DNA delta polymerase that is essential for DNA replication, DNA repair and chromatin remodeling in noncycling cells ${ }^{[28]}$. It has been reported that colchicine inhibited PCNA expression in mice renal tissue ${ }^{[29]}$. Bumbasirevie et al. (1996)[30] reported that colchicine resulted in cell death of cultured lymphocytes.

Proper control of infections by the immune system is ensured through the highly organized $\neg$ structure of the secondary lymphoid organs, that allow capture, processing, presentation of antigens and eventually leading to successful elimination of pathogens in addition to the induction of the adaptive immunity ${ }^{[31]}$. The spleen is the most important secondary lymphoid organ in the lymphoid system, with more lymphocytes passing through it each day than all the other lymphoid tissues combined ${ }^{[32]}$. Immunotoxicity is referring to any effect on the structure or function of the immune system or both which result in immune system dysfunction. Immune toxic effect is considered if impairing the humoral immunity (Blymphocytes) or cellular immunity (T-lymphocytes)needed by the host to defend itself ${ }^{[26]}$. Therefore, the present work clarified that colchicine had an immune toxic effect on the spleen through affecting its structure and both $\mathrm{B}$ and T-lymphocytes content.

\section{CONCLUSION}

Colchicine administration induced structural alteration of rat's spleen which was mild with short term use and marked with long term use. Therefore, the potential immune toxic effect should be considered by clinicians on its prescription.

\section{CONFLICTS OF INTEREST}

There are no conflicts of interest.

\section{REFERENCES}

1. Stringer MD, Smith AL and Wein AJ: Spleen. In: Gray's anatomy, the antatomical Basis of clinical practice; Eds Standring, 1st ed. Section 8: abdomen and pelvis. El-Sevier, Philadelphia, Baltimore, New York, London. (2016) pp. 1188 - 1193.

2. Ross $\mathrm{M} \mathrm{H}$ and Pawlina W: Lymphatic system: in histology a text and atlas with correlated cell and molecular biology. 7th ed. Wolters Kluwer Health, Philadelphia, London, Tokyo. (2016) pp. $442-487$.

3. Steven M. Williamsc LA and Eisenbartha SC: Structure-function of the immune system in the spleen. Sci Immunol. (2019) 4(33):1-25.

4. Nabila AR: Effect of colchicine on the histology of spleen and testis of albino rats. The Egyptian Journal of Hospital Medicine. (2006) 23:268-276.
5. Wagenaar Z: Accidental colchicines poisoning in a dog. Can. Vet. J. (2004) 45(1): 55-57.

6. Finkelstein Y, Aks SE, Hutson JR, Juurlink DN, Nguyen P, Dubnov-Raz G et al. Colchicine poisoning: the dark side of an ancient drug. Clin., Toxicol., (Phila). (2010) 48:407-414.

7. El-Shafeey A, El-Kasaby A and Soliman G: Histological and histochemical study of spleen of rats treated with colchicine. Egypt. J. Histol. (2000) 23(1- 2): 139-148.

8. Maxwell MJ, Muthu P and Pritty PE: Accidental colchicines overdose. A case report and literature review. Emerg. Med. J. (2001)19: 265-266.

9. Mori M, Oyamada M, Sakauchi F, Ogawa K: Effects of colchicine on the hepatocellular transport of indocyanine green in the rat. Virchows Arch B Cell Pathol Incl Mol Pathol. (1987) 53(1):37-43.

10. Drury RAB, and Wallington EA: Carleton's histological technique. 5th ed. Oxford, New York, Toronto: Oxford University Press. (1980) p.237

11. Chandler N: The Masson trichrome staining methods in routine laboratory use. stain technology journal. (1933) 8 (3): 101-110.

12. Smith FG, Murray PG and Crocker J: Correlation between PCNA and AgNOR scores in non-Hodgkin's lymphomas using sequential staining technique. J Clin Pathol. (1993) 46: 28-31.

13. Mohamed DS, Abdelhaliem NG and Zakaria AM: Histological and immunohistochemical study of the possible protective effect of ascorbic acid on the toxic effect of monosodium glutamate on the spleen of adult male albino rat. EJH. (2017) 40(1) 94-104.

14. Guven AG, Bahat E, Akman $\mathrm{S}$ and Atran, EM: Late diagnosis of severe colchicine intoxication. Pediatrics. (2002) 109 (5):971-973.

15. Elshama SS, El-Kenawy AE, Osman HEH: Hepatotoxicity and nephrotoxicity of colchicine prolonged use in the rats. International Journal of Advanced Research (2014) 2(4):1012-1023.

16. Steiniger B: Spleen. Encyclopedia of life sciences. John Wiley \& Sons. (2005) pp1-9.

17. Pabst $\mathrm{R}$ and Westermann $\mathrm{J}$ : The unique role of the spleen and its compartments in lymphocyte migration. Research in Immunology. (1991) 142(4): 339-342.

18. Ozdemir R, Bayrakci B and Teksam O: Fatal poisoning in children: acute colchicine intoxication and new treatment approaches. Clin., Toxicol. (2011) 49: 739-743. 
19. Brncic N, Ivica V, Relja P, Anoelko D, Dinko V and Draen C: Accidental Plant Poisoning with Colchicum autumnale: Report of Two Cases. Croat., Med., J. (2001) 42(6):673-675.

20. Eichenmuller B, Everley P, Palange J, Lepley $\mathrm{D}$ and Suprenant KA: The human EMAP-like protein-70 (ELP70) is a microtubule destabilizer that localizes to the mitotic apparatus. J Biol Chem. (2002) 277:1301-1309.

21. Tsukidate K, Yamamoto K, Snyder JW and Farber JL: Microtubule antagonists activate programmed cell death (apoptosis) in cultured rat hepatocytes. Am J Pathol. (1993) 143(3):918-925.

22. Mourelle M, Villalon $\mathrm{C}$ and Amezcua JL: Protective effect of colchicines on acute liver damage induced by carbon tetrachloride. Journal of Hepatology. (1988) 6: 337-342.

23. Ansari-Lari MA, Muzny DM, Lu J, Lu F, Lilley $\mathrm{CE}$, Spanos $\mathrm{S}$ et al. "A gene-rich cluster between the CD4 and triosephosphate isomerase genes at human chromosome 12p13". Genome Research. (1996) 6 (4): 314-326.

24. Van den Broek T, Borghans JA and Van Wijk F: "The full spectrum of human naive T cells". Nature Reviews. Immunology. (2018)18 (6): 363-373.

25. Hesketh M, Sahin KB, West ZE, Murray RZ: "Macrophage phenotypes regulate scar formation and chronic wound healing". International Journal of Molecular Sciences. (2017)18 (7): 1-10.
26. Shieh SJ, Varkey $\mathrm{P}$, Chen $\mathrm{PH}$, Chang SY. and Huang LLH: Counting CD4+ and CD8+ T cells in the spleen: a novel in vivo method for assessing biomaterial immunotoxicity. Regen Biomater. (2014) 1(1): 11-16.

27. Kristensen BW, Noer H, Gramsbergen JB, Zimmer $\mathrm{J}$ and Noraberg $\mathrm{J}$ : Colchicine induces apoptosis in organotypic hippocampal slice cultures, Brain Res. (2003) 964: 264-278.

28. Moldovan GL, Pfander B, Jentsch S: "PCNA, the maestro of the replication fork". Cell. (2007) 129 (4): 665-679.

29. Reddy RN, Latendresse JR, Mehendale HM: Colchicine antimitosis causes progression of S-(1,2-dichlorovinyl)-1-cysteine-induced injury leading to acute renal failure and death in mice. Toxicology. (2006) 220 (2-3):147-159.

30. Bumbasirevie V, Scaro-Milic A, Mireie A and Djurieie B: Apoptosis induced by microtubule disrupting drugs in normal murine thymocytes in vitro. Scanning Microscope (1996) 9: 509-516.

31. Borges da Silva H, Fonseca R, Pereira RM, Cassado Ados A, Álvarez JM, D'Império Lima MR: Splenic macrophage subsets and their function during blood-borne infections. Front Immunol. (2015) 6:1-9.

32. Bajénoff $\mathrm{M}$, Glaichenhaus $\mathrm{N}$ and Ronald $\mathrm{N}$ : Fibroblastic reticular cells guide t lymphocyte entry into and migration within the splenic $\mathrm{T}$ cell zone. J Immunol. (2008) 181:3947-3954. 
الملخص العربى

\section{أثر استخدام الكولشيسين على تركيب طحال ذكر الجرذ الابيض البالغ: دراسة هستولوجية وهستو كيميائية مناعية}

\section{ايناس أنور بخيت}

\section{قسم التشريح وعلم الأجنة كلية الطب جامعة عين شمس}

المقدمة: الكولثيسين قلوي طبيعي مستخرج من زعفران الخريف. يستخدم في علاج النقرس وفي الوقاية من نوبات حمى البحر المتوسط. فـ يتر اكم في العديد من الأعضاء مثل الطحال ويؤدي إلى تلفها. الهدف: هدف هذا العمل إلى دراسة الآثار المترتبة على استخدام الكولثيسين لمدة قصيرة ولمده طويلة على طحال ذكر الجرذ الابيض البالغ. المواد والطرق: تم استخدام خمسة وأربعين ذكرًا من الجرذان البيضاء البالغة في هذه الدر اسة ، الذين تتر اوح أعمار هم

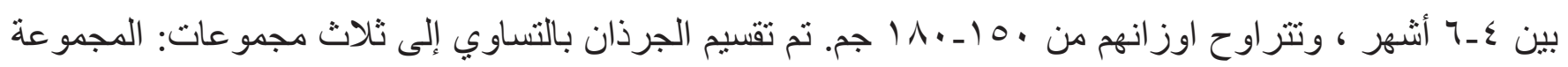
الأولى: تم تقسيمها بالتساوي إلى ثلاث مجمو عات فرعية :المجمو عة الفرعيةالاولى: تم الاحتفاظ بها كمجمو عة ضابطة سلبيه ، المجمو عة الفرعية الثانية: تلقت / مل من الماء المقطر / يومًيا عن طريق الفم لمدة سبعة أيام والمجموعة الفرعية الثالثة: تلقت / مل من الماء المقطر / يومًيا عن طريق الفم لمدة ـ ب يومًا. المجموعة الثانية: تلقت ب ملجم / كجم من وزن الجسم / يوميا من الكولثيسين عن طريق الفم لمدة سبعة أيام. المجموعة الثالثة: تلقت جر عة الكولثيسين كما في المجمو عة الثانية و لمدة • بـ يومًا. النتائج: كثف العمل الحالي أن إعطاء الكولثيسين لفترة قصيرة قد تسبب في حدوث تغيير هيكلي طفيف في طحال الجرذان في شكل انخفاض في حجم البصيلات اللمفاوية واحتقان الأوعية الدموية تحت الغطاء المحيط ، بينما لوحظت تغيير ات هيكلية كبيرة في طحال الجرذان في المجمو عة الثالثة والتى تلقت الكولثيسين لمدة طويلة في شكل فقدان التمبيز بين اللبين الأبيض والأحمر مع بصيلات لمفاوية غير محددة و احتقان فى الأوعية الدموية. الخلاصة: تسبب الكولثيسين في تغيير هيكلي فى تركيب الطحال للجرذان وكان التغير طفيفا مع الاستخدام قصير المدى وكبير امع الاستخدام على المدى الطويل. 